\title{
Mastering language use and usage: repositions perceived according to cognitive linguistics
}

\section{Dominando o uso e a utilização do idioma: preposições compreendidas de acordo com a linguística cognitiva}

Dominando el uso y la utilización del idioma: preposiciones comprendidas de acuerdo con la lingüística cognitiva

\author{
Sérgio Manuel Coelho Fernando ${ }^{1}$ \\ Alfrancio Ferreira Dias ${ }^{2}$
}

DOI: http://dx.doi.org/10.20435/serie-estudos.v22i46.1087

\begin{abstract}
Mastering prepositions has often been difficult for English language learners as a consequence of their polysemous nature and the sheer number of them in the English language. Most of the evaluations of the scientific output of the English language learners have established that prepositional addition, omission, and substitution account for most of the syntactic errors. For this reason, it is important for tutors to come up with effective instructional methods, since prepositions present such an immense challenge for the English language learners. Teaching prepositions are difficult due to various reasons. The present article has as objective the approach on the application of Prepositions and how structure and meaning may be perceived according to cognitive linguistics, based on other articles / books that served as bibliographical research for the construction of some ideas.
\end{abstract}

Key words: prepositions; cognitive linguistic; English Language.

Resumo: Dominar as preposições tem sido frequentemente difícil para estudantes de língua inglesa como conseqüência de sua natureza polissêmica e variedade na língua inglesa. A maioria das avaliações, de resultado científico, dos aprendizes da língua inglesa estabeleceram que a adição, a omissão e a substituição pré-posicionais representam a maioria dos erros sintáticos. Por esse motivo, é importante que os professores criem métodos de instrução eficazes, uma vez que as preposições apresentam um desafio imenso para os aprendizes da língua inglesa. As preposições de ensino são difíceis devido a várias razões. O presente artigo tem como objetivo a abordagem sobre a aplicação de preposições e como a estrutura e o significado podem ser percebidos de acordo com a linguística cognitiva, com base em artigos / livros que serviram de pesquisa bibliográfica para a construção de algumas ideias.

Palavras-chave: preposições; linguística cognitiva; Língua Inglesa.

Resumen: Dominar las preposiciones es con frecuencia difícil para estudiantes de la lengua inglesa como consecuencia de su naturaleza polisémica y variedad en la lengua inglesa. La mayor parte de

\footnotetext{
${ }^{1}$ Universidade Nova de Lisboa, Lisboa, Portugal.

2 Universidade Federal de Sergipe (UFS), São Cristóvão, Sergipe, Brasil.
} 
las evaluaciones, de los resultados científicos, de los aprendices de la lengua inglesa establecen que la adición, la omisión y la substitución preposicionales representan la mayoría de los errores sintácticos. Por esa razón, es importante que los profesores creen métodos de instrucción eficaces, una vez que las preposiciones presentan un desafío inmenso para los aprendices de la lengua inglesa. Las preposiciones de enseñanza son difíciles por varias razones. El presente artículo tiene como objetivo el abordaje sobre la aplicación de proposiciones y como la estructura y el significado pueden ser percibidos de acuerdo con la lingüística cognitiva, basado en artículos / libros que sirvieron de investigación bibliográfica para la construcción de algunas ideas.

Palabras clave: preposiciones; lingüística cognitiva; Lengua Inglesa.

\section{TEACHING PREPOSITIONS}

Teaching prepositions can be achieved through figurative language. First, the English language has a sheer number of prepositions, which contributes to the difficulty in learning them. Secondly, it is not easy to recognize the prepositions, especially in oral speech, for the reason that they contain very few syllables. Most of them are monosyllabic, which makes it difficult to distinguish them in rapid, naturally occurring speech. Lastly, prepositions are polysemous, which means that they are semantic of words that have more than one meaning. Due to these difficulties, the prepositions have time and again been a challenging issue for the teachers as well as the learners (LIU, 2014, p. 149).

Figurative language is perceived to be an aspect that gives a text specific esthetic value. Structures from this aspect are far from being decorative. They are pervasive and significant in language. Here, the appropriate cognitive structures are ubiquitous and vital in thought. Consequently, the figurative meaning makes up the core fabric of the grammatical structure. This is not only the case for unique literary language, but for the daily language, and it upholds for all the human languages. Figurative usage has various motivations, including metonymy and metaphor. Furthermore, polysemy is considered to be metaphorical in nature due to the association between many conventional meanings of a single word. Sometimes, the metonymy concerns the partwhole association, which permits the same name to be applied in many languages, for instance, leg and arm. For the English, the lexicon is full of polysemous words, which are multiple connected meanings for a nutshell appear to be the norm rather than the exception. On this note, the productive and living presence of the figurative process continually generates original and novel meanings (DANCYGIER; SWEETSER, 2014, p. 5). This, in turn, is useful when teaching prepositions to the English learners.

The two primary areas, in which the figurative language can be broadened when it comes to teaching prepositions, include the figurative uses of grammatical 
constructions, and the other is blending. On this note, the usage of the figurative language seems to be pervasive in all languages, including the English language. A reason for this is that the aspect reflects the pattern of the human cognition. Reflecting on figurative expression, requires the tutor to establish hypothesis concerning how the prepositions can present access to concepts, which are not associated with them. Besides, the figurative language usage is crucial when teaching prepositions, since it involves the unusual ways a teacher develops of saying something. These include paradox, personification, simile, metaphor, understatement, irony, hyperbole, and euphemism. Figurative language can be used for teaching prepositions in the classroom, because it is a vivid, active, and productive way to express meaning. By using this aspect, a teacher can say much more in fewer words. In regards to teaching prepositions, the figurative idea or object assists the learners to picture or understand the accurate perception. Aspect provides insight into the unfamiliar by comparing it to the familiar. What needs to be considered is the manner, in which the semantic representation of the conceptual patterns is founded on the human embodied experience and the way they are inhibited by the human cognition (DANCYGIER; SWEETSER, 2014, p. 25).

Figurative language is crucial when teaching prepositions, because the aspect adds interest and colour to the subject. It also helps the teacher to express the meaning of prepositions in a strong, vivid way. The different categories of the figurative language would enable the tutor to communicate a broader change of meaning when teaching prepositions than would be possible if they were limited to the literal language. For all that, using the figurative language to teach prepositions is an effective way, by which a teacher can communicate an idea, which is not understood easily due to its complexity or abstract nature.

Another way, through which teaching prepositions can be achieved, is through the use rhetoric. Speech is perceived to be a discipline and art that facilitates the learners understanding of the function and nature of symbols. This entails how the students view, what they experience, and what they know, and how they act as a consequence of their logo use and those, who are around them. Therefore, rhetoric is the expression that confines all of these processes. In regards to teaching prepositions, rhetoric is the human application of symbols to communicate. The second aspect of speech is a symbol. When teaching, this is when the tutor means that something represents or stands for something else by convention, association, and relationship. By contrast, the symbol is a human construction linked only directly to its referent. 
Rhetoric time and again entails the conscious and deliberate choice of symbols to communicate with the learners. In the Middle Ages, rhetoric played a role in education as one of the three liberal arts. On this note, rhetoric is perceived to make up the Trivium of learning along with grammar and logic (FOSS; FOSS; TRAPP, 2002, p. 9).

Rhetoric is also vital for teaching prepositions for the reason that it can be paired with Quadrivium, which includes music, astronomy, geometry, and arithmetic. As an element of the Trivium, rhetoric emphasises on various facets of style as well as classical figures of speech, which means that it is a practical art that offers the basis of founded liberal education. Furthermore, the proper and immediate province of rhetoric is the establishment of suitable arguments to prove a point of view, in this case teaching prepositions, and the skilful arrangement of them. When learning, a teacher can combine their knowledge of contemporary psychology and classical rhetoric to create rhetorical theories based on understanding the how prepositions are taught. Here, they need to present audience-centered approaches to speech and allow the contemporary concerns with an analysis of the learners. There is also the notion that rhetoric is sermonic, and that the rhetorical structures encode the worldviews and values. Furthermore, discourse is regarded as a concept of epistemic, and consequently, a product of social construction, which has a consistent pattern of discursive use that generates truth and knowledge (FOSS; FOSS; TRAPP, 2002, p. 16). Ideally, this can be crucial when teaching prepositions.

Moreover, using rhetoric is also vital, because it revolves around learning a collection of rules concerning how to write and speak effectively. Also, the central theme of rhetoric is persuasion, which is seen as only one of the many objectives of the aspect, with exposition being among them. However, speech should be viewed as a philosophical discipline that works as a mastery of the essential laws of the use of language. Speech-making begins with the evaluation of the words, the smallest unit for conveying meaning. In this case, if the learners first understand how the prepositions function as words, they will be capable of putting together larger messages for what they want to accomplish. This entails whether they wish to create, explain, or persuade a particular association with an audience. Besides, rhetoric is also studied and viewed as having focus in the order of knowledge. The speech offers the foundation of the effective educational curriculum at a time, when nothing is primary and central in the educational curriculum (FOSS; FOSS; TRAPP, 2002 , p. 23). This means that nothing provides a centre or holds it together around which prepositions can be taught. 
Using rhetoric when teaching prepositions are also crucial for the reason that it is concerned with how such words mean what they do. The meanings of the prepositions, as well as other words, are central to the theory of rhetoric. This is because rhetoric is a fundamental element in the sense of language as well as in the manner, in which such knowledge serve the user of the words. Purposes help or mediate as a mirror for the learners in their willing, feeling, and thinking between all the volitional, affective, and cognitive activities as well as with the reality, with which these operations are concerned. Furthermore, based on the readings in contemporary rhetoric, there are various ways of eliminating misunderstandings when it comes to teaching prepositions. This includes using specialised quotations marks, literary context, definition, and metaphor. Skilled quotations marks are essential for helping the learners determine the intended meaning of prepositions. The literary context is an additional method to get rid of misunderstanding when teaching prepositions. Definition of words, in this case, when teaching the prepositions is also useful in removing misunderstanding Comprehensive definitions of references when teaching prepositions can make the learning more profitable by bringing the students into an open disagreement or agreement with each other. The metaphor is as well a vital method for facilitating comprehension, when it comes to teaching prepositions (FOSS; FOSS; TRAPP, 2002, p. 33).

Another concept that is essential when it comes to teaching prepositions is the use of metaphor. This aspect is critical when learning for the reason that it governs the peoples' thoughts both as a matter of intellect as well as to the most mundane details. This shows that based on linguistic evidence, most of the ordinary conceptual system of the humans is metaphorical in nature. Essence of metaphor when teaching prepositions are experiencing and understanding one kind of thing based on another. Since the metaphorical expressions in the English language are attached to the metaphorical aspects methodically, the teacher can apply the manifestations of the metaphorical linguistics to teach the nature of the metaphorical concept. This is crucial in understanding the metaphorical nature of learning the prepositions. Moreover, in the classroom, the metaphorical aspects can be expanded beyond the assortment of conventional literal approaches of talking and thinking into the range of what is referred to as fanciful language or thought, colourful, poetic, or figurative (LAKOFF; JOHNSON, 2003, p. 14).

Another concept is the orientational metaphors, and they have a basis on the people's cultural and physical experience. There are also the ontological 
metaphors, which the teachers can use when teaching prepositions, so that the students can comprehend states, activities, actions, and events. One of the distinct ontological metaphors is personification. This will enable the learners to understand diverse experiences with entities that are not human based on human activities, characteristics, and motivations. The metaphors allow the tutor to differentiate the form of the argument from the contente and works by satisfying an objective, which, in this case, is for the learners to understand the aspect of prepositions. The application of metaphors as an instructional strategy can only be achieved to its fullest potential when the tutor applies it in all part of the content. This is done as a way to assist the learners in generating a mental model that serves as a frame for conceptual knowledge. Therefore, the metaphors can be used to help students understand the abstract or new concept by providing unfamiliar information in a context that is familiar. It is evident that the metaphors pervade the standard conceptual system of people. This is so since the aspects are crucial, when concepts are not delineated or abstract in the daily experience (LAKOFF; JOHNSON, 2003, p. 16).

The three aspects of metaphors that make the concept significant when teaching prepositions include first using it as a referent to understanding learning and education have the potential to transform what transpires in the classroom. Second, a teacher can use metaphor in the classroom as a generative component to create new knowledge. Third, the teacher can use metaphors to describe teaching. Metaphors are as well considered to be a vital aspect of thinking. Learners need to get a grasp on prepositions, which are abstract to them using other characters, which are in terms that are clearer. This shows that metaphors enable the students to understand one domain of experience based on another. This demonstrates that the comprehension transpires based on the whole fields of experience and not based on concepts that are isolated. Besides, metaphors are crucial when teaching prepositions, because they have a feedback effect, which guides the future actions of the students by the metaphor. Using the metaphors is as well suitable for the reason that they help students to set goals, justify inferences, and sanction actions. Additionally, the meaning that metaphor will have for the student when learning prepositions will be partly tied to their past experiences and culturally determined (LAKOFF; JOHNSON, 2003, p. 143).

The use of metaphor is recommended in explaining classroom interaction and teacher planning. It includes the association between practice and metaphor, imagery, and thoughtful planning. Besides embellishing language, the metaphor also promotes 
a comprehensive understanding of phenomena and concepts, in this case teaching prepositions. As such, using the metaphor is crucial in clarifying the mentoring relationship as well as the complexities of mentoring (MAHAPATRA, 2004, p. 100).

\section{HOW STRUCTURE AND MEANING MAY BE PERCEIVED ACCORDING TO COGNITIVE LINGUISTICS}

Despite being a clear strategy to the study of language, the cognitive linguistics is as well among the most speedily growing schools in linguistics in the present day. In regards to cognitive linguistics, meaning and structure may be perceived in various ways, with one based on the seductiveness of the cognitive language. This aspect arises from the fact that the objective of the cognitive language is an incorporated model of thought and speech of the generation of a sharp theory of meaning in linguistics, which reflects the construal of external reality of the humans. This also considers the manner, in which human being experience reality both psychologically and culturally. In its depiction of natural language, both on structure and meaning, the cognitive linguistics attempts to bridge the distance between the code and actual use of code, the system, and the real use of the scheme as well as the social and psychological. Cognitive linguistics is also made up of a structure that is flexible rather than a single theory of language. The aspect also constitutes models of scientific descriptions, which are not single, neatly delineated, but rather bundles of approaches that are time-competitive, and at the same time, closely associated (GEERAERTS, 2006, p. 167).

Additionally, the linguistic meaning is flexible and dynamic, because meaning is sensitive to the contextual influences, and that the users of a language apply their semantic groupings to modifications of the conditions. Similarly, the linguistic meaning is considered to be perspectival. Here, since meaning is depicted as a means of influencing the outside world, this calls for the understanding of two concepts, which include grammatical construal and cognitive grammar. Another way, through which structure and meaning may be perceived according to cognitive linguistics, is that the sense of linguistics is non-autonomous and encyclopaedic. On this note, the notion that meaning has to do with the manner, in which people interact with the globe, is supported. This implies that the structure and meaning reflect on the overall social, cultural, and biological experience as human beings. The focus is based on the favourite aspects of mental spaces, image schema as well as metonymy and metaphor, all of which gain an updated and renewed treatment. Lastly, the meaning 
of linguistic is based on experience and usage. In this case, it is argued that both meaning and structure are crucial, when it comes to the use of language for the application of our knowledge of the tongue. This, in turn, guides the learners to three original models. These are usage-based linguistics, construction grammar, and frame semantics (GEERAERTS, 2006, p. 170).

Additionally, the cognitive linguistics represents a wide-ranging paradigm shift in linguistics, and that the interest in an intralinguistic and interlinguistic variation of language makes up the cornerstone of the change in that model. The development of structure and meaning is widely featured by a succession of three steps of theory formation. These include the cognitive-functional one, the generative one, and the structuralist one. Furthermore, the cognitive linguistics adopts an experiential view of view of structure and meaning. When these two aspects are constructed in and through the language, they are not perceived as an independent and separate module of the mind, but it replicates the human beings overall experience. What is more, the cognitive linguistics applies a usage-based representation of language. This is roughly in the logic there is a dialectal association between use and structure. For this reason, the personal usage occurrences are attainments of an existing systematic structure. Nevertheless, the changes might be introduced into the structure only through the individual usage events (GEERAERTS, 2006, p. 173).

Another way that structure and meaning may be perceived, according to cognitive linguistics, is whereby people influence the exact behaviour of each. This is achieved through the desire for distinctiveness and by the opposition, and in some cases, by adaptation and co-operative imitation. This shows that the research on the cultural-linguistic variation is a critical notion of cognitive linguistics. The rationale for this results from the historical position of cognitive linguistics in the establishment of contemporary linguistic. What is more, structure and meaning may be perceived, according to cognitive linguistics, by arguing that language is governed by the wide-ranging cognitive principles, instead of the special-purpose language form. An additional aspect, in which the meaning of a word generates a reference to external entities, is that the word enables the audience as well as the speaker to pay attention only to part of a whole frame. This is because no word provides the full structure of the outline.

According to the cognitive linguistics, the structure as well as meaning may be perceived as mainly being concerned with exploring the association between the socio-physical experience, the mind, and language. Cognitive linguistics also places 
central significance on embodied experience, conceptual processes, meaning as well as structure in mind and the study of language, and the manner, in which they interconnect. In cognitive style, the constructional meaning is the notion that is linked to the family of construction grammars. In this case, the construction has a traditional definition that is tied to it. This includes resultative construction, let alone construction, intransitive construction, and motion development. Cognitive linguistics has two commitments. The first is the generalisation one, which signifies a devotion to set apart the common standards that apply to aspects of the human language, including structures and meaning. Moreover, the research on cognitive linguistics pays attention to what is ordinary among the areas of language. Consequently, it attempts to re-apply satisfactory explanations and methods across these dimensions (EVANS; BERGEN; ZINKEN, 2007, p. 3).

In the second place, there is also the cognitive commitment, which characterizes the commitment to offer a representation of the general principles of language that concur with what is known concerning the brain and the mind from other disciplines. Besides, this commitment embodies the notion that the scientific structure principles should portray the knowledge concerning the human cognition from the other brain and cognitive science. These include philosophy, cognitive neuroscience, artificial intelligence, and psychology. The cognitive linguistics can be divided into cognitive grammar and cognitive semantics. The cognitive semantics has four guiding principles, which include meaning construction, meaning representation, grammatical structure, and conceptual structure. On this note, in regards to cognitive linguistics, the theoretical structure may be perceived as a result of the temperament of the human being embodiment, which implies that it is embodied (EVANS; BERGEN; ZINKEN, 2007, p. 13).

What is more, the cognitive approaches to grammar are based on a cognitive semantics, and it establishes an aspect of linguistic knowledge, which is consistent with the finding of work in cognitive semantics and assumptions. The cognitive approaches to grammar have two guiding principles, which include the usage-based thesis and the symbolic thesis. Based on the symbolic thesis, the cognitive approaches to grammar are largely independent of meaning and are widely applied in evaluating the concepts of grammatical structures. The usage-based thesis, on the other hand, highlights that the speaker has a mental grammar that is produced by the construct of symbolic units from positioned examples of language use. The analytical results of this conception are that there are no upright differences between the use of language 
and the knowledge of language, since having an understanding of the language is as well the knowledge of how to use the language. This also includes how the structure and applied in the verbal communication. Additionally, the cognitive linguistics has had numerous achievements in regards to how meaning and structure are perceived. This has been obtained through the incorporation of functionalist and formalises concerns. On the one hand, the functionalists have been mainly apprehensive with surveying the communicative as well as the standard operations of the use of situated language. In the second place, the formalists are primarily concerned with forming the portrayal of understanding of language in mind and with coming up descriptively suitable depictions of the linguistic phenomenon (EVANS; BERGEN; ZINKEN, 2007, p. 30).

\section{CONCLUSION}

Prepositions provide good evidence that prepositional meanings are expanded from a spatial domain to more abstract domains in a systematic and restrictive way. We conclude that a study of prepositions in the light of Cognitive Linguistics offers more accurate and systematic explanations that, in turn, provide a basis for a more coherent and accessible presentation to the learner of this apparently arbitrary aspect of English grammar.

For the authors, language teachers put certain difficulties, through challenges, in the learning of their students, noting that in their spatial meanings, the prepositions do not fit well from one language to another. As mentioned (AARTS, 2006, p. 113), "[...] grammar comprises syntax (the study of sentence structure) and morphology (the study of the structure of words). 'Grammar' can also refer to a physical object, i.e., a book, and one can felicitously say "I have at least six different grammars of English on my bookshelf". A grammar in this sense is a description of a language, and can be written from different perspectives. Thus, school grammars have as their aim to teach the basic principles of grammar. They are usually simplified and can be relatively unsophisticated. They also tend to be prescriptive in outlook, rather than descriptive. School grammars were very widely used in the 18th and 19th centuries. Similar in their aims, but more modern in outlook, because they are based on research in modern linguistics and are descriptive in outlook, are pedagogical grammars. These are used in many different teaching environments: secondary schools, foreign language teaching schools, as well as universities. Nineteenth century descriptive accounts of particular languages are called traditional grammars, while their modern (i.e., post-1950) counterparts are usually referred to as descriptive grammars or 
reference grammars. Sometimes we don't even notice the physical sense because "humans regularly extend their understanding of physical-spatial relations and entities to non-physical domains; these extended conceptualizations are regularly reflected in the linguistic system" (TYLER; EVANS, 2003, p. 28).

We also need to highlight the following quotation:

CG view of linguistic organization presents two major advantages. First, by emphasizing the symbolic nature of all linguistic expressions, it allows the instructor to focus on the meaning of grammatical constructions. This focus on meaning in turn provides useful insights into the form of those constructions, since meaning can be shown to motivate form [...]. It also allows the instructor to make explicit the semantic relations that obtain with other related constructions. From a methodological standpoint, the recognition of the meaning of grammatical constructions provides opportunities to teach grammar in a way similar to that of lexical items, which makes grammatical instruction congruent with the principles of most contemporary communicative models of language pedagogy, such as processing instruction, content-based teaching, task-based teaching for example. Secondly, the adoption of the CG principles places the speaker squarely in the center of the communicative act. (ACHARD, 2008, p. 432).

Trying to keep in mind Payne's perspective (PAYNE, 2011, p. 12) in the preface of his Undestanding English Grammar - A Linguistic Introduction:

The grammar of a language is a dynamic, constantly changing set of habit patterns that allows people to communicate with one another. For some reason, many in academia and language teaching seem to have lost sight of this common sense truth, preferring to treat grammar as though it were an object, outside of human beings in society, consisting of absolute categories and rules. This misperception has led to a deep tension between theoreticians and the practical needs of language teachers, whose students often come to believe that grammar is a tedious classroom subject, to be endured as a kind of rite of passage, rather than a key to the amazing world of human communication.

An indisputable fact about each English preposition is that it is associated with a complex set of uses, distributed in compounds involving prepositions arising from a limited set of principles. Each proto-scene is understood as the constitution of a representation of the primary sense associated with a particular preposition, from which they form systematically derivative meanings. Thus, each preposition and its associated multiple uses are represented as an organized network and related meanings, rather than arbitrary lists of distinct meanings that share the same lines in phonological form. 
We come to the idea that linguistics provides a description of English prepositions substantially more accurately and systematically than traditional ones. There is the notion that the traditional forms of linguistic propositions have resulted in a series of imprecise characterizations of prepositions. These characterizations, in turn, led to claims of the meanings of English prepositions and idiosyncrasies. Although there is no particular approach for teaching prepositions, it is evident that the traditional strategy of teaching them is not suitable. On this note, there are other effective means such as the use of figurative language, metaphors as well as rhetoric. These techniques are crucial for teaching prepositions, because they expose the learners to a plethora of input. These methods also consider other words apart from the prepositions, which makes them ideal. According to the cognitive linguistics, the structure and meaning may be perceived in various ways, since while the concept is functionalist in spirit, it is apprehensive in both modellings the language as a phenomenon that is cognitive and attaining descriptive adequacy (EVANS; BERGEN; ZINKEN, 2007, p. 30).

\section{REFERENCES}

AARTS, B. Grammar. In: BROWN, K. (Ed.) Encyclopedia of language \& linguistics. 2. ed. Estados Unidos: Elsevier Science, 2006.

ACHARD, M. Teaching construal: cognitive pedagogical grammar handbook of cognitive linguistics and second language acquisition. New York: Routdledge, 2008.

EVANS, V.; BERGEN, B. K.; ZINKEN, J. (Ed.). The cognitive linguistics reader. London: Equinox, 2007.

DANCYGIER, B.; SWEETSER, A. Figurative language. Cambridge: Cambridge University Press, 2014.

FOSS, K. A.; FOSS, S. K.; TRAPP, R. Readings in contemporary rhetoric. New York: Waveland Press, 2002.

GEERAERTS, D. Cognitive linguistic. New York: Mouton de Gruyter, 2006.

LAKOFF, G.; JOHNSON, M. Metaphors we live by. Chicago: University of Chicago Press, 2003.

LIU, D. Describing and explaining grammar and vocabulary in ELT: key theories and effective practices. New York: Routledge, Taylor \& Francis Group, 2014.

MAHAPATRA, B. C. Models of teaching in education: with special preference to researches in synatics and gaming models of teaching. New Delhi: Sarup \& Sons, 2004.

PAYNE, T. E. Undestanding English Grammar- a linguistic introduction. New York: Cambridge University Press, 2011. 
TYLER, A.; EVANS, V. The semantics of english prepositions: spatial scenes, embodied meaning and cognition. New York: Cambridge University Press, 2003.

\section{About the authors:}

Sérgio Manuel Coelho Fernando: Graduate in Letters - English, Post Graduate in Methodologies of the English Language and Portuguese Language. Post Graduate in English Language Teaching. Attending Master's Degree in English Didactics at Universidade Nova de Lisboa, Portugal. E-mail: prof.sergiofernando@gmail.com

Alfrancio Ferreira Dias: PhD in Sociology, Professor at the Graduation Program in Education at the Federal University of Sergipe. Researcher of the Study Center of Interdisciplinary Researches on Women and Social Relations of Gender (Núcleo de Estudos e Pesquisas Interdisciplinares sobre a Mulher e Relações Sociais de Gênero - NEPIMG/UFS). E-mail: diasalfrancio@gmail.com

\section{Received in june of 2017}

\section{Approved for publication in september of 2017}


